\title{
National Horticultural Science Societies of the World
}

\author{
John G. Seeley ${ }^{1}$ \\ Cornell University, Ithaca, NY 14853
}

While serving as ASHS Representative to the Consortium of Associations for International Programs (CAIS) of the American Association for the Advancement of Science, I was asked for information about national horticultural science societies throughout the world. Since this information was not available, we conducted a survey.

We selected 83 countries from a list of 172 . We prepared a short questionnaire, which asked for the name, address, phone numbers, name of chief executive officer, purpose(s), number of members, and publications of each society, and sent copies to horticulturists, primarily members of ASHS or the International Society for Horticultural Science (ISHS), or acquaintances through horticultural activities. We requested similar information if the country has a horticultural science society similar to ASHS. Information about officers is not presented because these change with time.

During the last 4 years, we received responses from $87 \%$ of the countries. Forty-four have a horticultural science society. Twentyeight do not have a society of that type, but many have horticultural associations or societies for amateur gardening, amenity horticulture, crop producers, crop sciences, arboriculture, and plant propagation. Eleven countries did not respond.

In some countries, research and education in horticultural science is not through a specific national society. For instance, in the Netherlands there is no national society, but horticulturists are active in ISHS.

Readers with information about horticultural science societies not included in this article are encouraged to submit such information to ASHS Headquarters.

An excellent source of information about international research is Horticultural Research International, a directory of horticultural research institutes and their activities in 63 countries, published by ISHS, Englaan 1, 6703 ET Wageningen, Netherlands.

\section{Argentina}

Asociaci6n Argentina de Horticultural (ASAHO)

501 y 149 -J. Gorina ( 1896), Argentina

phone 54-(021) 840443

Purpose: To promote, stimulate, and favor all those national activities related with horticultural research, education, and extension through a) the annual organization of the Argentina Congress of Horticulture, b) the promotion of regional meetings on horticultural science and technology, and c) the publication of the journal Horticultural Argentina. 320 members.

Publication: Horticultural Argentina.

\begin{abstract}
Australia
Australian Society of Horticultural Science (AuSHS)

P.O. Box 581

Gosford, N. S. W., Australia 2250

phone 61-043-28-0300

Purpose: To encourage the scientific and scholarly study of horticulture; to advance the introduction of scientific principles and practices into horticulture; to promote the profession of horticultural science; to introduce and implement codes of management and ethics for the profession; to provide scientific and technical advice to government and industry organizations engaged in regulating horticultural trade; and to foster communication with the Australian Institute of Agricultural Science, the International Society for Horticultural Science, and other kindred societies both national and international. Founded 1991.
\end{abstract}

Emeritus Professor of Floricultural Science, Dept. of Floriculture and Ornamental Horticulture. Appreciation is extended to Skip McAfee, former ASHS executive director, who assisted in the preparation of this article.
Brazil

Sociedade de Olericultura do Brasil (SOB)

Caixa Postal, 277

88.300- Itajaí, SC, Brazil

phone 55-(0473) 44-3677; telex 473-443 ECPA-BR

purpose: To promote national and international interest in development in horticulture in all branches through a) the sponsorship of an annual congress to provide a forum for research reporting and public discussion on horticultural problems, b) the dissemination of horticultural knowledge through publications, and c) the development of mutual understanding among individuals and organizations concerned with the science of horticulture. 730 members.

Publications: Horticultural Brasileira (2 issues/year); SOB Informa (2 issues/year); and SOBre Hortaliça (4 issues/year).

\section{Canada}

Canadian Society for Horticultural Science (CSHS)

c/o Agricultural Institute of Canada

151 Slater St., Suite 907

Ottawa, Canada KIP 5H4

phone 6131232-9459; fax 613/594-5 190

Purpose: To promote and foster the science of horticulture in Canada. 300 members

publication: Canadian Journal of Plant Science.

\section{Chile}

Sociedad Agronomic de Chile

Alonso Ovalle 1638

Santiago, Chile

phone 56-712290

Purpose: To promote interest in scientific and technological research and education in agriculture and all its branches through a) publication of Simiente, b) sponsorship of an annual meeting, and c) development of mutual understanding among individuals and organizations concerned with horticultural and agricultural science. Founded 1910.702 members. Publications Simiente (2 to 4 issues/year) and Boletin Tecnico (irregular).

China, People's Republic of (PRC) Chinese Society for Horticultural Science (CSHS)

30 Bai Shi Qiao Rd., West Suburb

Beijing 100081, China

phone 86-8314433-2629

Purpose: To promote horticultural development, enhance the growth of scientific personnel, and carry out domestic and international academic exchange to contribute to the realization of our modernization. 10,000 members.

Publication: Acts Horticultural Sinica (4 issues/year).

China, Republic of (ROC)

Chinese Society for Horticultural Science

Dept. of Horticulture

National Taiwan University

Roosevelt Rd., Sec. 4

Taipei, Taiwan, R.O.C.

phone 886-(02) 3625542; fax 886-(02) 3625542

purpose: To promote national interest in scientific research and education in horticulture and to promote international cooperation and exchange in horticultural science and technology through a) the sponsorship of meetings, forums, lectures, and discussions on horticultural research, education, and public policies; b) the dissemination of horticultural knowledge through the publication of the Journal; c) the participation in national and international horticultural matters; and d) the development of mutual understanding and cooperation among individuals and organizations concerned with horticulture. 380 members. 
Publication: Journal of the Chinese Society for Horticultural Science (4 issues/year).

\section{Colombia}

Federación Nacional de Productores de Hortalizas y Frutales (Fede Hortofruticola)

Cane 37

15-49 Bogota, Colombia

phone 57-(91) 2455213 or 57-(91) 2873384

Purpose: National union through common purposes, organization, services. Enlargement of markets by motivating consumption (internal) and solidifying and opening markets (external). 1195 members. Publication: Horticultural Moderns (3 issues/year).

Czechoslovakia, Republic of

Horticultural Science Society of the Czech Republic

[Vedecka zahradnicka spolecnost (VSZ) Ceske republiky]

Faculty of Horticulture VSZ

69144 Lednice na. Mor., Czech Republic

phone 42-6279841 1; fax 42-62798411

purpose: To promote and encourage national and international interest in scientific research and education in horticulture in all its branches. Founded 1990.70 members.

\section{Denmark (see Scandinavia)}

\section{Egypt}

Egyptian Society for Horticultural Science

14 Gamrad Housny

Kaser E1-Niel, Cairo, Egypt

Purpose: To promote and encourage the national interest in horticultural research and education through annual meetings and the distribution of the journal. 1000 members.

Publication: Egyptian Journal of Horticultural Science (2 issues/year).

\section{Finland (see Scandinavia)}

\section{Germany}

German Society for Horticultural Science

(Deutsche Gartenbauwissenschaftliche Gesellschaft e.V.)

Herrenhauser Str. 2

D-3041 9 Hannover 21, Germany

phone 49-0511 762-2638; fax 49-0511762-3606

Purpose: To stimulate horticultural science and take further measures that contribute to the aim of horticultural science through a) organization of scientific meetings, b) promotion of scientific travels at home and abroad, c) cultivation of relationships to other connected disciplines, and d) support of development of junior scientists. 367 members.

Publication: Gartenbauwissenschaft (6 issues/year).

\section{Ghana}

Ghana Association of Agriculture

Faculty of Agriculture

University of Ghana

Legon-Accra, Ghana

phone 233-775380; fax 233-21-668577

Purpose: To create the awareness and to boost the confidence of Ghanaian horticulturists, and to explore areas in horticulture that have not yet been explored in Ghana. 62 members.

\section{Greece}

Greek Society for Horticultural Science (GrSHS)

Laboratory of Biology, Horticulture Dept., School of Agriculture

Aristotelian University of Thessaloniki

GR.-54006 Thessaloniki, Greece

phone 0031-31992579

Purpose: To improve scientific knowledge of the members; to improve horticultural science by promoting and encouraging national interest in scientific research and education in horticulture; to develop mutual understanding among persons concerned with the science of horticulture; and to disseminate new horticultural knowledge in Greece through scientific national meetings, symposia, and lectures. Founded 1966.130 members.

Publication: Proceedings ofthe Greek Societyfor Horticultural Science.

\section{Hungary}

Horticultural Society for Hungarian Agricultural Sciences

(Magyar Agrártudományi Egyesület Kertészeti Társaság)

Kossuth Lajos tér 6-8

Budapest, Hungary 1055

phone 36-(1) 531-950; telex 227-591

Purpose: To promote and encourage national interest in scientific research and education in horticulture in all its branches and to give information about the latest results of the science and the new technology in horticulture. 1200 members.

Publications: Kertgazdág (Horticultural) (6 issues/year); and Agrárvilág (Agricultural World) (monthly).

\section{Iceland (see Scandinavia)}

\section{India}

Horticultural Society of India (HSI)

c/o Division of Fruits and Horticultural Technology, IARI

New Delhi- 110012, India

phone 91-386055; telex 031-622-49-ICAR-IN

Purpose: To promote the science and practice of horticulture. 300 members. Publication: Indian Journal of Horticulture.

\section{Indonesia}

Indonesian Horticultural Society

(Perhimpunan Hortikultura Indonesia, or Perhorti)

Horticulture Section, Dept. of Agronomy

Institut Pertanian Bogor (IPB)

Jalan Raya Pajajaran, Beranangsiang

Bogor 16143, Indonesia

phone 62-(025 1) 328799; fax 62-(0251) 312708

Purpose: To encourage horticulturists from different institutions to work together, to promote horticultural development in Indonesia, and to improve the knowledge of members. 200 members.

Publications: irregular.

Italy

Italian Horticultural Society (SOI)

(Società Orticola Italiana)

Via G. Donizetti, 6

50144 Firenze, Italy

phone 391-055/361688; fax $391-055 / 331497$

Purpose: To promote a) studies, research, exhibits, and initiatives designed to further the progress, improvement, dissemination, and development of the horticultural sciences; b) a mutual understanding between research workers and growers; c) the preservation of the nation's gardens and of its arboreal and hort-floricultural heritage as well as the ecological conservation of its territory; d) the development of mutual understanding with similar national and international societies, and e) the participation in international events of horticultural interest. 1897 members.

Publication: Notiziario di Ortoflorofrutticoltura (6 issues/year).

\section{Japan}

Japanese Society for Horticultural Science (JSHS)

c/o Dept. of Agronomy and Horticultural Science

Faculty of Agriculture, Kyoto University

Sakyo-ku, Kyoto 606, Japan

Purpose: To promote and encourage national and international interest in scientific research and education in horticulture in all its branches through a) the sponsorship of an annual meeting to provide a forum for research reporting and public symposia on horticultural research, b) the dissemination of horticultural knowledge through publication of the Journal, c) the participation and offering of leadership in national and international horticultural matters, and d) the development of mutual understanding among individuals and organizations concerned with the science of horticulture. 2492 members. 
Publication: Journal of the Japanese Society for Horticultural Science (4 issues/year).

Korea, Republic of

Korean Society for Horticultural Science (KSHS)

c/o Dept. of Horticulture

Seoul National University

Suwon, 440-744, Korea

phone 82-0331-44-2120, ext. 268; fax 82-0331-46-5830

Purpose: To promote and encourage regional and national interest in scientific research and education in horticulture in all its branches through a) the sponsorship of meetings twice a year to provide a forum for research reporting and special lectures of invited guest speakers on horticultural research; b) publication of the Journal and other publications; and c) the development of mutual understanding and friendship among members. Founded 1963.892 members.

Publications: Journal of the Korean Society for Horticultural Science (4 issues/year); and summary of papers presented at national meetings (2 issues/year).

\section{Malaysia}

Malaysian Society for Horticultural Science (MSHS)

(Persatuan sains Hortikultur Malaysia)

Jabatan Agronomi \& Hortikultur

University Pertanian Malaysia

43400 UPM Serdang, Selangor, Malaysia

phone 60-03-9486101-10, ext. 2624; fax 60-03-9483745; telex MA 37454

Purpose: To act as the official body representing the professional interest of the horticulturist and horticultural scientist in Malaysia, to be involved in planning horticultural development in Malaysia through consultation, coordination, and participation, and to promote, encourage, and contribute to improving and upgrading standards in research, investigation, education, extension, and dissemination of knowledge related to horticulture through seminars, conferences, symposia, and publications related to horticulture. Founded 1991.61 members.

\section{Mexico}

Sociedad Mexicana de Ciencias Hortícolas (SOMECH)

c/o Centro de Fruticultura, Colegio de Postgraduados

Chapingo, Mexico 56230

phone 52-595422, ext. 5418

purpose: To encourage the scientific development of horticulture through publications, a biannual congress, and promoting events such as symposia, conferences, expositions, and excursions; to standardize horticultural terminology; to develop relationships with other scientific societies; and to encourage and support actions toward protection of biotic resources. 800 members.

Publication: Horticultural Mexicana (2 issues/year).

\section{Namibia (see Southern Africa)}

New Zealand

New Zealand Society for Horticultural Science (NZSHS)

P.O. Box 19560

Christchurch, New Zealand

phone 64-(03) 842 432; fax 64-(03) 252944

Purpose: To improve the professional standing of members, to promote research in horticultural science, to foster high standards in education and extension, to make available and disseminate new information, to increase public awareness of the role of horticulture in the economy, and to represent the viewpoints of the profession to decisionmakers. Founded 1981.250 members.

Publication: New Zealand Agricultural Science.

\section{Nigeria}

Horticultural Society of Nigeria (HORTSON)

c/o National Horticultural Research Institute

P.M.B. 5432, Idi-Ishin

Ibadan, Nigeria

phone 234-022-412490

Purpose: To pursue the advancement and development of the science and art within all branches of horticulture in Nigeria through research, meetings, symposia, conferences, seminars, demonstrations, and concerted extension services throughout the country. Founded 1977.315 members.

Publications: Proceedings of the annual conference; Nigerian Journal of Horticultural Science (one issue/year); and HORTSON Newsletter (2 issues/year).

\section{Norway (see Scandinavia)}

Poland

Polish Society for Horticultural Science

Al. 29 Listopada 54

31-425 Kraków, Poland

phone 48-11-13-00

Purpose: To develop the scientific and educational activities of its members in horticultural research in all the fields, particularly pomology, vegetables; ornamental plants, horticultural plant breeding, apiculture, and landscaping. Founded 1987.350 members.

Publication: Folia Horticultural (2-3 issues/year).

\section{Portugal}

Portuguese Horticultural Association

(Associação Portuguese de Horticultural e Fruticultura)

Rua da Junqueira 299

1300 Lisboa, Portugal

phone 351-1.633719

Purpose: To advance horticultural science through specialized meetings, workshops, technical visits to horticultural areas, and publications. 510 members.

Publication: Folha Informative (newsletter 4 issues/year).

\section{Romania}

Romanian Society of Horticulture (SRH)

(Societatea Româna de Horticultural)

Bd. Carol nr. 17, sector 2

Bucuresti, Romania

phone 40-13.02.19

Purpose: To promote interest, progress, and efficiency in horticultural science research and education; to organize and support scientific and professional activities and dissemination of knowledge; and to improve relations among all organizations and people involved in horticulture. Founded 1913, refounded 1991.2700 members.

Publication: Horticultural.

\section{Scandinavia}

Scandinavian Association of Agricultural Scientists (NJF):

Section III (Horticulture)

(Nordiska Jordbruksforskares Forening)

Okemveien 145

$\mathrm{N}-0580$ Oslo 5, Norway

phone 47-2 647270; fax 47-2630671

Purpose: To initiate and improve cooperation in research and education in agriculture and horticulture among Denmark, Finland, Iceland, Norway, and Sweden through workshops, symposia, common research projects, and doctoral courses. Founded 1918.395 members. Publications: Nordiske Jordbrugsforskning (quarterly) and Acts Agricultural Scandinavia: Series B (Soil and Plant Science) (quarterly).

\section{Singapore}

Singapore Institute of Biology

c/o Botany Dept.

National University of Singapore

Kent Ridge, Singapore 0511

phone 65-7756666

purpose: To promote the advancement of biology and its applications; to encourage the improvement of education and training in biology; to advance the character and status of biologists; to facilitate the exchange of information in biology and its applications; to publicize and disseminate information about biology; and to secure and distribute 
grants and loans for education and research in biology and its applications. 207 members (20 in horticulture).

Publication: Bulletin of the Singapore Institute of Biology (4 issues/ year).

South Africa (see Southern Africa)

\section{Southern Africa}

Southern African Society for Horticultural Sciences (SASHS) [Suider-AfrikaanseVerenigingvirTuinbouwetemkappe(SAVTW)] Private Bag X 11208

Nelspruit 1200, South Africa

phone 27-131 1-52071; fax 27-1311-23854

Purpose: To improve and encourage scientific communication in all horticulture-related disciplines in Southern Africa (includes South Africa, Namibia, Swaziland, and Zimbabwe); to improve international contact, communication, cooperation, and affiliation; and to enhance and encourage a strong unity and close relationship between all related horticultural sciences in Southern Africa. Founded 1988.347 members. Publications: Journal of the Southern African Society for Horticultural Sciences; and Newsletter of the Southern African Society for Horticultural Sciences.

\section{Spain}

Sociedad Española de Ciencias Horticolas (SECH)

Apartado 3048

14080 Cordoba, Spain

phone 34-57-218501; fax 34-57-218569

Purpose: To promote and encourage national and international interest in scientific research, education, and extension in horticulture in all its branches through a) the development of relationships among persons and institutions concerned with horticulture; b) the participation in activities related to horticulture; c) the dissemination of horticultural knowledge through publication; d) the organization of biannual congresses to provide a forum for research reporting, lectures, etc.; and e) the establishment of relationships with other national and international scientific societies. Founded 1981.544 members.

Publications: Actas de Horticultural (nonperiodic proceedings); and Boletin Informativo (quarterly newsletter).

\section{Swaziland (see Southern Africa)}

\section{Sweden (see Scandinavia)}

\section{Thailand}

Horticultural Science Society of Thailand

Dept. of Agricultural Extension

Phaholyothin Rd.

Chatuchak, Bangkok 10900, Thailand

phone 66-2-5793804; fax 66-2-5793786

Pm-pose: To transfer horticultural crop production technologies to members and to develop horticultural production for agribusiness. 250 members.

\section{Tunisia}

\section{Tunisian Society for Horticultural Science (ATSH)}

(Association Tunisienne des Sciences Horticoles)

c/o Institut National Agronomique de Tunisie (INAT)

43, Avenue Charles Nicolle

1082- Tunis Mahrajiène, Tunisia

phone 216/1-280.950; fax 216/1-289. 166

Purpose: To promote and encourage national interest in scientific research and education in horticulture in all its branches through a) the sponsorship of meetings and symposia to provide a forum for research reporting, lectures, and public discussion on horticultural research, $b$ ) the participation and offering of leadership in national and international horticultural matters, and c) the development of mutual understanding among individuals and organizations concerned with the sciences of horticulture. 70 members.
United Kingdom

The Royal Horticultural Society

80 Vincent Square

London SW1P 2PE, United Kingdom

phone 49-071-834 4333; fax 49-071-6306060

Purpose: To encourage, educate, and improve the science, art, and practice of horticulture in all its branches via: three gardens (Wisley, Rosemoor, and Hyde Hall); publications; flower shows (including the Chelsea and the Hampton Court Palace shows); an advisory service; cultivar trials; a range of plants; distribution of seeds; supporting overseas plant expeditions; maintaining the Lindley technical horticulture library; advising government departments; and promoting horticulture and gardening through the media. Founded 1804.175,000 members.

Publications: The Garden (monthly); The New Plantsman; and The Orchid Review.

\section{United States}

American Society for Horticultural Science (ASHS)

113 South West St., Suite 400

Alexandria, VA 22314-2824

phone 703/836-4606; fax 703/836-2024

Purpose: To promote and encourage national and international interest in scientific research and education in horticulture in all its branches. Founded 1903.5000 members.

Publications: Journal of the American Society for Horticultural Science (6 issues/year); HortScience (monthly); HortTechnology (quarterly); and ASHS Newsletter (monthly).

\section{Uruguay}

Sociedad Uruguaya de Horticultural (SUH)

Soriano 1346 P.1

11100 Montevideo, Uruguay

phone 598-2-9172 60; telex 26236 UY-DSV; fax 598-2-396508

Purpose: To encourage the study of vegetable science and to promote vegetable research; to disseminate the results of technical work and research in vegetables; to help other institutions in finding solutions for improving the socioeconomic situation of the vegetable sector; to promote extensive work and production in vegetables; and to exchange information in the study of vegetable science with other countries from Latin America. Fruit science was included in SUH in 1989.170 members. Publications: Abstracts of biannual meeting of vegetable science; and Correo Horticola (newsletter 3 issues/year).

\section{Venezuela}

Sociedad Venezolana de Horticultural

P.O. Box 162

Cagua 2122, Estado Aragua, Venezuela

phone 58-(044) 79184

Purpose: To promote events (congresses, seminars) and publications about horticulture (fruits, vegetable crops, and flowers) in Venezuela; and to give an opportunity to know and get to know the work that is being done in this area. 300 members.

Publications: Annual bulletin and proceedings of meetings.

\section{Yugoslavia}

Union of Horticultural Societies of Slovenija

(Zveza Hortikulturnih Drustev Slovenije)

Miklosiceva c.4

Ljubljana 61001, Yugoslavia

phone 38-(061) 219-416

Purpose: Education, lectures, dissemination of knowledge, propagation of horticultural plants, expositions, and protection of nature. 21 societies, about 41,500 members (in 1989).

Publication: Zeleni bilten (Green Bulletin).

\section{Zimbabwe (see Southern Africa)}


Countries without a National Horticultural Science Society

Austria, Belgium, Costa Rica, Cyprus, Ethiopia, France, Honduras, Ireland, Israel, Jordan, Kenya, Kuwait, Latvia, Luxembourg, Malawi, Mauritius, Moldova, Morocco, Netherlands, Pakistan, Philippines, Saudi Arabia, Seychelles, Sri Lanka, Switzerland, Tanzania, Turkey, and Zambia.
Countries with No Response

Bangladesh, Bulgaria, Lesotho, New Guinea, Peru, Russia, Senegal, Sierra Leone, Sudan, Surinam, and Ukraine. 